\title{
Bovine Serum Prolactin, Growth Hormone, and Triiodothyronine Levels during Late Pregnancy and Early Lactation
}

\author{
Tetsu JoHKe and Kouichi Hodate \\ Department of Physiology, National Institute of Animal \\ Industry, Chiba-shi 280
}

(Received July 14, 1977)

\begin{abstract}
Changes of serum prolactin (PRL), growth hormone (GH), and triiodothyronine (T3) levels in Holstein dairy cows during late pregnancy and early lactation were determined by radioimmunoassays. The cows calved in September. Mean serum PRL ranged $9.9 \mathrm{ng} / \mathrm{ml}$ to $12.4 \mathrm{ng} / \mathrm{ml}$ during the $3 \mathrm{rd}$ to 7 th day prepartum. It increased to a peak value of $87.3 \mathrm{ng} / \mathrm{ml}$ on the day of parturition from $57.5 \mathrm{ng} / \mathrm{ml}$ on the day before calving, and decreased to $13.9 \mathrm{ng} / \mathrm{ml}$ within 3 days postpartum. During the 2 nd to 30 th day prepartum, serum GH varied between 2.4 and $4.0 \mathrm{ng} / \mathrm{ml}$ and increased to $8.0 \mathrm{ng} / \mathrm{ml}$ on the day of calving. During a week postpartum, serum GH ranged from 5.2 to 8.2 $\mathrm{ng} / \mathrm{ml}$. Mean serum GH during a week postpartum was higher than that of prepartum $(\mathrm{P}<0.001)$. Mean serum T3 level during 5 days prepartum varied 104.2 to $108.8 \mathrm{ng} / \mathrm{d} l$ and decreased to $93 \mathrm{ng} / \mathrm{d} l$ on the day of calving. During 5 days postpartum, mean T3 level varied 73.0 to $83.8 \mathrm{ng} / \mathrm{d} l$. Contrary to $\mathrm{GH}$, mean serum T3 level during 5 day postpartum was significantly lower than that of prepartum $(\mathrm{P}<0.001)$.
\end{abstract}

It has been shown that administrations of prolactin (PRL), growth hormone (GH), gluococorticoids, and thyroid hormone restore or reinitiate lactation after hypophysectomy in goats ${ }^{1)}$ and sheep ${ }^{2}$. In the small ruminants, the combination of these hormones is considered to be essential for milk secretion after pituitary ablation ${ }^{1,2}$. On the other hand, little has been known about bovine lactogenic hormones in vivo. Previous studies demonstrated a PRL surge around parturition in the cows ${ }^{3-6}$. However, there have been limited studies on circulating levels of GH and thyroid hormones during lactogenesis in cows. In the present report, changes of serum PRL, GH, and triiodothyronine (T3) levels in Holstein dairy cows during late pregnancy and early lactation are described.

\section{Materials and Methods}

Experimental animals and blood sampling. Five Holstein dairy cows, 3 to 5 years of age, expected to be 2nd to 4th caving from the Institute herd were used. The cows calved in September. After parturition, calves were separated and the cows were milked twice daily at 08:30 and 18:30 h. Jugular venous blood samples were obtained by venipuncture between 15:30 and 16:30 h. Serum was separated by centrifugation and stored at $-20^{\circ} \mathrm{C}$ until assay.

Radioimmunoassays for prolactin, growth hormone, and triiodathyronine. Serum PRL levels were estimated by a radioimmunoassay method using bovine PRL (NIH-P-B2) as the stand$\operatorname{ard}^{7,8)}$. Serum GH was determined by a double antibody method using bovine GH (NIH-GH-B12)

Jap. J. Zootech. Sci., 48, (12): 772-776. 
as the standard hormone ${ }^{8)}$. Serum T3 concentration was estimated by T3 RIA kits (Dinabot Radioisotope Laboratory).

\section{Results}

Prolactin. From 3 to 7 days prior to parturition, serum PRL levels in 5 cows ranged between $9.9 \pm 3.2 \mathrm{ng} / \mathrm{ml}$ and $12.4 \pm 2.9 \mathrm{ng} / \mathrm{m} l$ (Mean $\pm S$. E.). The value increased to a peak of $87.3 \pm$ $22.3 \mathrm{ng} / \mathrm{ml}$ on the day of calving from $57.5 \pm 23.7 \mathrm{ng} / \mathrm{ml}$ on the day before parturition (Fig. 1). The level decreased to $13.9 \pm 3.3 \mathrm{ng} / \mathrm{ml}$ on the $3 \mathrm{rd}$ day postpartum. The value varied $9.0 \pm 2.8$

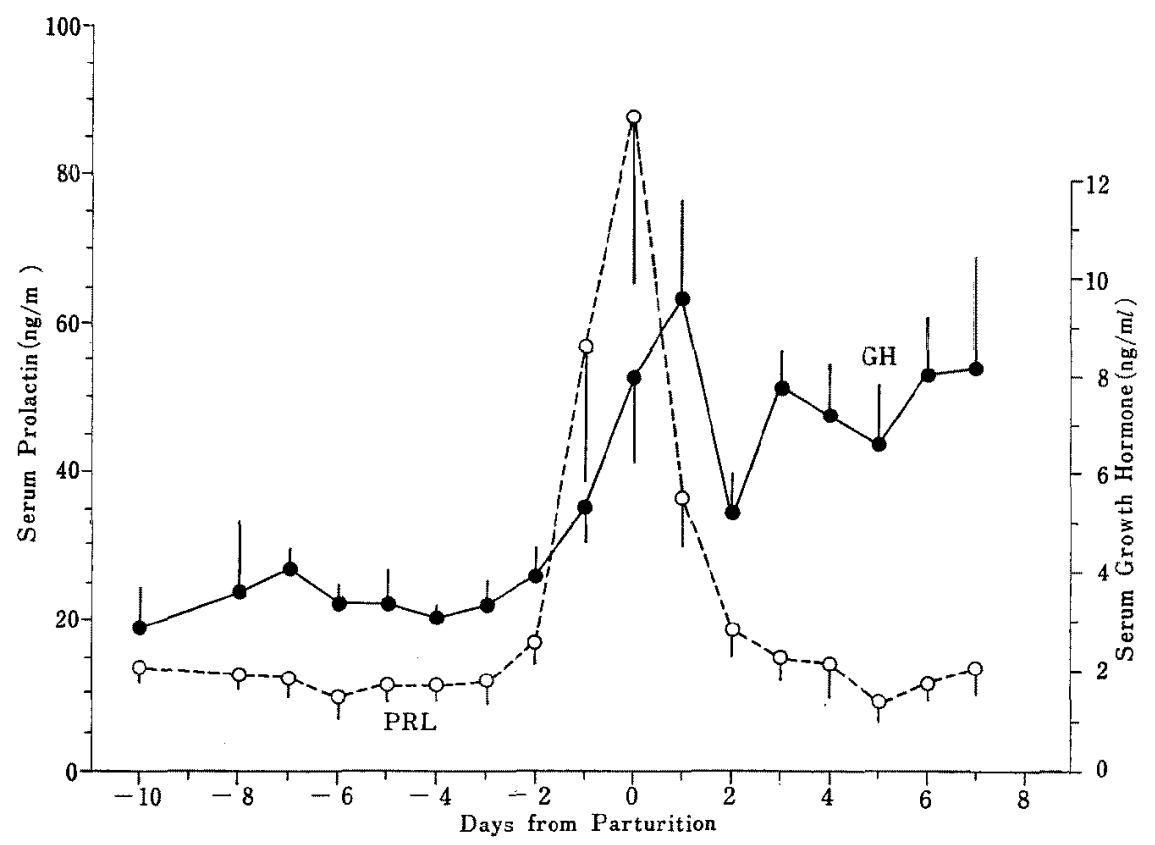

Fig. 1. Serum PRL (o) and GH (•) concentrations around parturition in the dairy cows. Each point and vertical bar indicate the mean and standard error (S. E.) of 5 determinations.

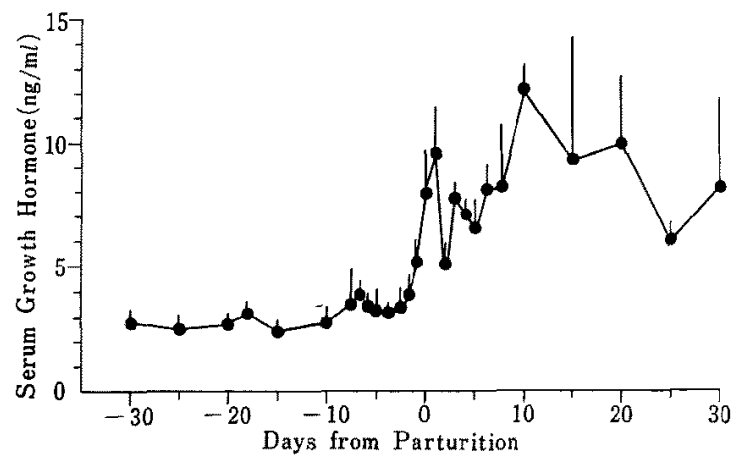

Fig. 2. Serum GH concentrations during late pregnancy and early lactation in the dairy cows. Each point and vertical bar represent the mean and S. E. of 5 obsevations. 


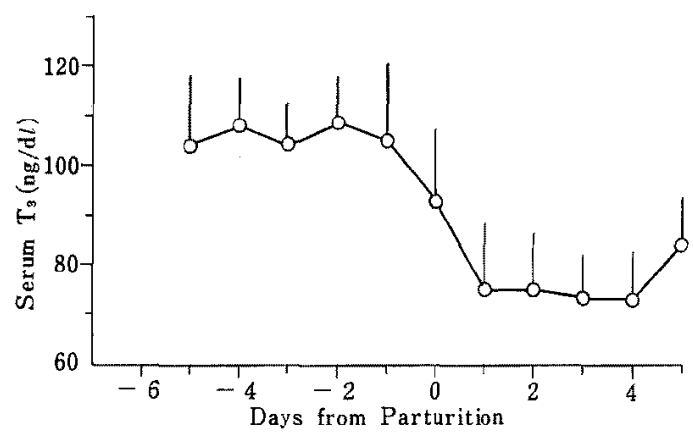

Fig. 3. Serum T3 level around calving in the dairy cows. Each point and vertical bar indicate the mean and S.E. of 5 observations.

$\mathrm{ng} / \mathrm{m} l$ to $13.9 \pm 3.3 \mathrm{ng} / \mathrm{m} l$ during 4 th to 7 th day postpartum. No significant difference was observed between the mean serum PRL level during 2nd to 7th day prepartum and that during 2nd to 7 th day postpartum.

Growth Hormone. Until 2 days before parturition, serum GH varied between $2.4 \pm 0.5 \mathrm{ng} / \mathrm{ml}$ and $4.0 \pm 0.4 \mathrm{ng} / \mathrm{ml}$ during a month prepartum (Fig. 2). On the day of parturition, serum GH level increased to $8.0 \pm 1.8 \mathrm{ng} / \mathrm{ml}$ from $5.3 \pm 0.7 \mathrm{ng} / \mathrm{ml}$ on the day before parturition (Fig. 1). In postpartum, serum GH concentration varied between $5.2 \pm 0.8 \mathrm{ng} / \mathrm{ml}$ and $12.2 \pm 1.2 \mathrm{ng} / \mathrm{ml}$. Mean serum GH level during 7 days postparum was significantly higher than that during 7 days prepartum $(\mathrm{P}<0.001)$.

Triiodothyronine. Serum T3 levels were determined from 5 th day prepartum to 5 th day postpartum. During 5 days prepartum, serum T3 showed little change and ranged between 104.2 $8.9 \mathrm{ng} / \mathrm{d} l$ and $108.8 \pm 9.9 \mathrm{ng} / \mathrm{d} l$ (Fig. 3). The value decreased to $93.0 \pm 16.3 \mathrm{ng} / \mathrm{d} l$ on the day of parturition. The postpartum levels varied between $73.0 \pm 12.2 \mathrm{ng} / \mathrm{d} l$ and $83.8 \pm 10.1 \mathrm{ng} / \mathrm{d} l$. The mean serum $\mathrm{T} 3$ level in postpartum was significantly lower than that in prepartum $(\mathrm{P}<0.001)$.

\section{Discussion}

The occurrence of a marked PRL surge near parturition confirmed our previous report ${ }^{4)}$ and other's ${ }^{3,5,6)}$. The serum level in PRL surge near parturition varied with season as in the case of response to milking or $\mathrm{TRH}^{8,9)}$. The observed increase of plasma $\mathrm{GH}$ level near parturition is in agreement with the results in heifers ${ }^{6)}$ and cows $^{10)}$. Furthermore, the mean serum GH level during a week postpartum was significantly higher than that of prepartum, though a marked day to day variation was observed. Although many factors to elevate serum PRL and GH in cows have been clarified, the factors to enhance PRL and GH secretion around parturition have not been well established.

One of the possibilities is the conspicuous increase of circulating level of estrogen and precipitous drop of progesterone ${ }^{11,12)}$. Administration of estrogen increased plasma concentrations of $\mathrm{PRL}^{13)}$ and $\mathrm{GH}^{(4)}$ in the cows. Another possibility is the effect of stress associated with parturition. It has been found that stressful stimuli enhanced PRL release in cattle ${ }^{15-18)}$. Bovine GH did not respond to stress such as venipuncture ${ }^{8,18}$. However, there is a possiblity that GH respond to "severe" stress such as parturition. Removal of the fetus by the caesarian section induced a marked increase of plasma concentrations of PRL and GH in the cows ${ }^{19}$. Although caprine pros- 
taglandin $F$ concentration in vena caval plasma near parturition paralleled with that in uterine vein ${ }^{20)}$, and prostaglandin $\mathrm{F}_{2} \alpha$ administration induced a marked increase of plasma concentrations of PRL and GH in heifers ${ }^{21}$, physiological significance of circulating prostaglandin $F$ for enhanced secretion of both hormones near parturition in ruminants remains to be elucidated. Increase in PRL and GH secretions by enhanced endogenous TRH release around parturition is not likely, for there was no appreciable rise of plasma TSH near parturition (Johke and Hodate unpublished data). During later stage of pregnancy, high placental lactogen concentrations in blood may suppress PRL and GH secretion from the pituitary gland in the cow. Bovine placental lactogen has both GH-like and PRL-like activities ${ }^{22}$.

The elevated levels of plasma PRL and GH around parturition presumably accelerate lactogenesis in the cow. Suppression of $\mathrm{PRL}$ secretion around parturition by administration of 2-Br$\alpha$-ergocryptine, a PRL inhibitor, or $2-\mathrm{Br}$ - $\alpha$-ergocryptine and an antiserum to bovine $\mathrm{PRL}$, induced a marked depression of lactogenesis in the cows ${ }^{23.24}$. Furthermore, the concentrations of $\alpha$-lactalbumin, lactose, and caseins in colostrum and milk decreased significacantly in the $\operatorname{cows}^{2 * 1}$. It was been well established that $\mathrm{GH}$ has a potent galactopoietic activity in lactating cows ${ }^{25,36)}$. The rise of serum GH level around calving and during postpartum may also be responsible for a marked increase in milk secretion during early stage of lactation. No marked change of serum thyroxine level was found during late pregnancy and early lactation in cows ${ }^{27)}$. The low serum thyroxine level was also reported in lactating cows as compared to that of dry cows ${ }^{28)}$. The decline in plasma T3 level in postpartum may be attributable to an increased $T 3$ utilization in peripheral tissues by enhanced general metabolism in lactation.

The authors are grateful to Professor C. H. LI, University of California, U. S. A., for generous gift of purified bovine GH, and to National Institute for Arthritis, Metabolism and Digestive Diseases, U.S.A., for providing purified bovine PRL and GH.

\section{References}

1) Cowie, A.T., and J.S. Tindal, The Physiology of Lactation Edward Arnold I.t. London. 1971.

2) Denamur, R., J Dairy Res 38: 237-264. 1971.

3) Schams, D., and H. Karg, Zbl Vet Med A 17: 193-212. 1970.

4) Johke, T., H. Fuse, and M. Oshma, Jap J Zootech Sci 42: 173-179, 1971.

5) Edgerton, L. A., and H. F. HaFs, J Dairy Sci 56: 451-458. 1973.

6) Ingalls, W. G., E. M. Convey, and H. D. Hafs, Proc Soc exp Biol Med 143: 161-164. 1973.

7) Jонке, T., Endocrinol Japon 16:581-589. 1969.

8) Joнке, T., Endocrinol Japon (submitted).

9) Joнke, T., Jap J Zootech Sci 47: 183-191. 1976.

10) Olsen, J. D., A. Trenkle, D. A. Witzel, and J.S. McDonald, Am J Vet Res 35: $1131 \cdots 1134$. 1974.

11) Smith, V. G., L. A. Edgerton, H. D. Hafs, and E. M. Conqey, J Anim Sci 36: 391-396. 1973.

12) Robertson, H. A., J Reprod Fert 36: 1-7. 1974.

13) Schams, D, and H. KARG., Acta endocr 69: 47-52. 1972.

14) Trenkle, A., J Anim Sci 31: 389-393. 1970. 


\title{
JOHKE and HODATE
}

15) JoHkE, T., Endocrinol Japon 16: 179-185. 1969.

16) Jонке, T., Endocrinol Japon 17: 393-401. 1970.

17) Raud, H. R., C.A. Kiddy, and W. D. Odell, Proc Soc exp Biol Med 136: 686-693. 1971.

18) Tucker, H. A., J Animal Sci Suppl. 1: 137-141. 1971.

19) Shirlex, J.E., R. S. Emery, E. M. Convey, and W. D. Oxender, J Dairy Sci 56:569-574. 1973.

20) Umo, I., R. FitzPatrick, and W. R. WARD, J Endocr 68: 383-389. 1976.

21) Lours, T. M., J. N. Stellflug, H. A. Tucker, and H. D. Hafs, Proc Soc exp Biol Med 147: 128-133. 1974.

22) Bolander, F. F. Jr., L. C. Ulberg, and R. E. Fellows, Endocrinology 99: 1273-1278. 1976.

23) Schams, D., V. Reinhardt, and H. Karg, Experientia 28: 697-699. 1972.

24) JoHke, T., and K. Hodate, Endocrinol Japon (submitted).

25) Mertes, J., Milk: The Mammary Gland and it's Secretion (Kon, S. K. and A. T. Cowie eds) Vol. 1. p 321-367. Academic Press. New York and London. 1961.

26) Machlin, L. J., J Dairy Sci 56: 575-580. 1973.

27) ShodA, Y., and T. Ishi, Jap J Zootech Sci 47: 659-664. 1976.

28) Lorscheider, F. L., W. D. Oxender, and E. P. Reineke, Fed Proc 28: 319. 1969. (Abstract).

\section{乳牛の血清プロラクチン, 成長ホルモンおよびトリヨード サイロニンの妊娠末期から泌乳初期に打ける変化}

\author{
上家 哲・甫立孝一 \\ 農林省畜産試験場，千葉市 280
}

9 月に分婏した経産ホルス隹ホン㮔乳牛の妊娠末期か ら泌乳初期に扔ける血清プロラ少チン (PRL)，成長木

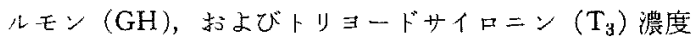
の変化をシジオイムノフッセイで測定して次の結果を 得た。（1）娃娠末期の平均血清 PRL 值以，分婏 3 日前立 で大きな変化を示さなかった斿，分浼2 日前加ら上昇し て，分婏の日に最高值 $87.3 \mathrm{ng} / \mathrm{ml}$ を示した，分婏㣪は 低下して，4 日以降のレベル结娠末期之ほぼ同様であ った（2）娃娠末期の平均血清 $\mathrm{GH}$ 值は，分婏 2 日前ま で 2.4 4.0 ng/mlの閶它変動したが，分婏 1 日前から
上昇して，分娩日には $8.0 \mathrm{ng} / \mathrm{ml}$ の最高値を示した，分 婏後 $\mathrm{I}$ 週間の血清 $\mathrm{GH}$ 值は 5.2 8.2 ng/ml であった が，その平均値は，分婏前 1 週間の值上的有意儿高名

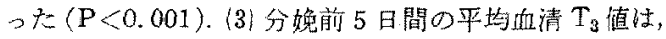
$104.2 \sim 108.8 \mathrm{ng} / \mathrm{d} l$ であったが，分媿日には $93 \mathrm{ng} / \mathrm{d} l$ に 減少した。分婏後 5 月間のレベルは $73.0 \sim 83.8 \mathrm{ng} / \mathrm{d} l$ で あったが，文の平诗值は分婏前にくらべて有意に氐かっ 夫 $(\mathrm{P}<0.001)$. (4) 分婏前娞におけ可乳牛の血清 PRL, $\mathrm{GH}$ および $\mathrm{T}_{3}$ 它変化させるいくつかの装因について論 莪した。 